\section{Do Christians Need to Reconcile Evolutionary Theory and Doctrines of Divine Providence and Creation?}

\author{
Stephen C. Meyer \\ in The 71st Annual Meeting of the Evangelical Theological Society
}

https://doi.org/10.54739/aa4w

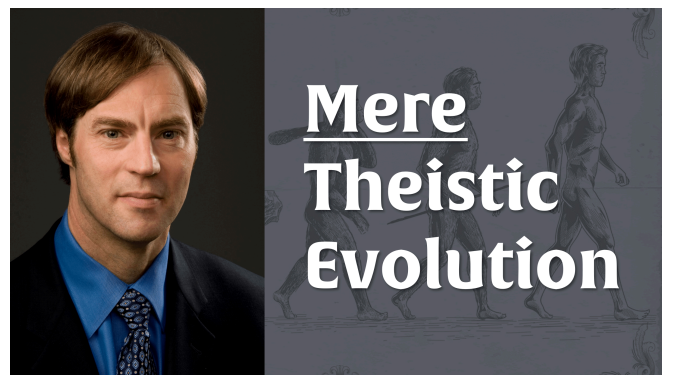

Many Christian scholars have argued that standard versions of evolutionary theory and orthodox theological commitments can be reconciled. Some theistic evolutionists or "evolutionary creationists" have argued that evolutionary mechanisms such as random mutation and natural selection are nothing less than God's way of creating. Though I dispute the logical coherence of these attempted reconciliations elsewhere, I argue here that there is little reason for Christians to attempt them, since an accumulating body of evidence from multiple subdisciplines of biology casts doubt on the creative power of the main evolutionary mechanisms. Thus, rather than addressing the question, "Can a meaningful doctrine of divine providence or creation be reconciled with mainstream evolutionary theory?" this essay will address the question of whether Christians should, or need to, attempt such a reconciliation at all.

appreciate, first of all, the invitation to be part of this panel, and the interest that Michael Murray and John Churchill have shown in our book. I designed and helped edit the scientific and philosophical sections of the book and wrote a scientific and philosophical introduction to it. I also appreciate the irenic tone of Murray and Churchill's opening remarks, as well as those of William Lane Craig and Tom McCall. I am looking forward to the conversation afterward. There is a lot to build on, especially in the previous remarks. Two important questions are either stated, or implied, in the introduction to Murray and Churchill's paper: could, or by implication should, Christians with traditional doctrinal commitments accept theistic evolution-what they call "mere theistic evolution"?
This article was first presented in a session of The 71st Annual Meeting of the Evangelical Theological Society. It was then published, closed access, in Philosophia Christi.

\section{Can We Reconcile Evolutionary Theory and the Doctrine of Creation?}

Murray and Churchill address the first question in their paper. There they argue that Christians can reconcile the doctrines of divine providence and creation with mainstream evolutionary theory as they understand it. They also indicate that they accept the adequacy of the evolutionary processes affirmed by neo-Darwinists and/ or by advocates of the so-called extended evolutionary synthesis.

In the introduction to the volume under

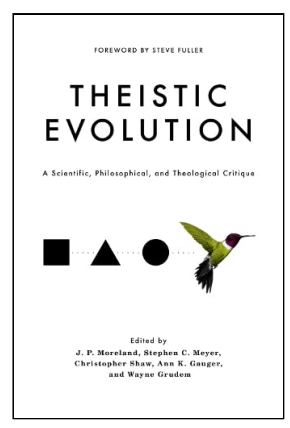
discussion here ${ }^{1}$ I dispute this

reconciliation thesis. In particular, I argue that there is a significant logical tension between orthodox evolutionary theory with its affirmation of apparent, but not actual, design in living organisms, on the one hand, and any notion of a purposeful divine creation on the other. In that introduction, I make clear that randomness-as in the random mutation part of the neo-Darwinian mechanism-is not the only point of tension between these two systems of thought. Consequently, I doubt that simply redefining randomness epistemically, rather than ontologically, resolves that apparent tension. Instead, I argue that other aspects of the neo-Darwinian mechanism undermine any robust notion of teleology-in particular, the role that natural selection plays in both classical and modern Darwinism in replacing artificial or intelligent selection (that is, actual design) as an explanation for adaptation and other forms of apparent design in living systems.

In the introduction to the volume, I acknowledge that there are, strictly speaking, ways to achieve a logically consistent reconciliation between evolutionary ideas (though not exactly mainstream evolutionary theories) and a theological doctrine of creation. But I argue that even these reconciliation strategies come at a great epistemic cost in the form of loss of (1) parsimony, (2) empirical content and, thus, scientific relevance and (3) explanatory power. I don't think our friends opposite have grappled fully with these points

1. Meyer, Stephen C. "Scientific and Philosophical Introduction," in Theistic Evolution: A Scientific, Philosophical, and Theological Critique, ed. J. P. Moreland, Stephen C. Meyer, Chris Shaw, Ann K. Gauger, and Wayne Grudem (Wheaton, IL: Crossway, 2017), 23-51. 
in their critique, and so I commend my scientific and philosophical introduction to them for further review and evaluation.

\section{Do Christians Need to Reconcile Evolutionary Theory and the Doctrine of Creation?}

In the interest of space, however, I'd like to set the question of the possibility of reconciliation aside in part because I think we have yielded far too much authority to mainstream or consensus science concerning the adequacy of neo-Darwinian and other proposed evolutionary mechanisms. So rather than ask, "Can we reconcile orthodox evolutionary theory with orthodox theological commitments?" I want instead ask: "Should we, or need we, affect such a reconciliation?"

By that I mean the following: are Christians under an epistemic obligation to accept the claims of orthodox evolutionary theory?-in particular, do we need to accept claims about the adequacy of the neo-Darwinian mechanism, and those additional mechanisms formulated by proponents of the extended evolutionary synthesis?

Murray and Churchill have clearly embraced three distinct meanings of evolution. Those three meanings are (1) change over time, (2) common descent (in its most general form, universal common descent, or Darwin's tree of life rooted in the last universal common ancestor), and (3) the sufficiency of undirected natural processes, chief among them random mutations and natural selection (but supplemented by other processes, including whatever may fall under the heading of the extended evolutionary synthesis), to explain the functional complexities of organisms. They especially embrace the third meaning, which I think is the most philosophically and theologically significant. They say, "implicit in what follows ... is an endorsement of evolution as a very good explanation of (the complexity of life), and not simply the best (explanation) among a rather poor set of candidates."

So they embrace the empirical claims of evolutionary theory, in particular, the adequacy of its proposed mechanisms as an explanation for the origin of the complexity of living systems. That claim is what I'd like to focus on here. Should Christians accept evolutionary theory? Where again "should" here means are we under an epistemic obligation to accept these claims?

I want to say no, and I would like to tell you a story that illustrates why. In November 2016, I attended a conference organized by the Royal Society in London. The Royal Society arguably is one of the most august scientific bodies in the world. The conference was called by leading evolutionary biologists who wanted to examine what they called "new trends in evolutionary theory."2 These evolutionary biologists increasingly reject neo-Darwinism and the idea that the mechanism of random mutation and natural selection can explain the origin of anatomical novelty and biological complexity. These biologists were exploring prospects for formulating new mechanisms that could possibly explain the kind of complexity that we see in novel living systems as they arise in the history of life.

2. See "New Trends in Evolutionary Biology: Biological, Philosophical and Social Science Perspectives," The Royal Society, https://royalsociety.org/science-eventsand-lectures/2016/11/evolutionary-biology.
The opening talk at the conference was given by Gerd Müller, a prominent evolutionary theorist from Austria. ${ }^{3}$ One of his introductory slides was captioned "The Explanatory Deficits of the Modern Synthesis." These deficits included problems like the "origin of phenotypic complexity" (the complexity of visible organismal traits) and the "origin of anatomical novelty" (the origin of major

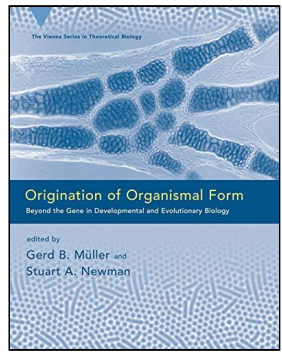
new innovations in the history of life).

Müller's list of explanatory deficits also included the discovery that many of the mutational processes we observe are actually biased or directed toward propitious outcomes in just the way that neoDarwinism denies when it claims that all mutations are random. Indeed, biologists have discovered that organisms possess a kind of preprogrammed adaptive capacity that sometimes directs mutational processes toward specific outcomes under a kind of algorithmic control. This preprogrammed adaptive capacity depends upon a complex information processing system that itself requires prior explanation. (I personally think it exhibits evidence of intelligent design). In any case, Müller highlighted other explanatory deficits of neo-Darwinism such its inability to explain the origin of "non-gradual modes of transition," meaning the abrupt appearance in the fossil record of major groups of plants and animals.

In 2003, Müller coedited a book from MIT Press with biologist Stuart Newman. ${ }^{4}$ In their opening essay, they stated that although neoDarwinism is still the mainstream evolutionary theory, it has "no theory of the generative." Indeed, many evolutionary biologists have recently explained that neo-Darwinism explains small-scale variation very well, but it doesn't explain major morphological innovations-that is, the origin of novel forms of life. In fact, in their 2003 volume Newman and Müller list the origination of novel "Organismal Form" as one of many significant unanswered questions in biology. When I first encountered their essay-around 2004-it struck me as quite extraordinary because the origin of novel biological form was the fundamental question Darwin was supposed to have answered in 1859. Now, instead, we have leading evolutionary biologists telling us that question has not been answered.

There is an oft-repeated aphorism among evolutionary biologists that reflects this situation. Many now say natural selection and random mutations "explain the survival, but not the arrival, of the fittest." We heard this quoted a number of times at the 2016 conference. The Dutch geneticist Hugo de Vries apparently first said this in $1904,{ }^{6}$ but it has become a common aphorism among evolutionary biologists

3. Gerd Müller's November 7, 2016, Royal Society talk is available as an MP3 file: http://downloads.royalsociety.org/events/2016/11/evolutionary-biology/ muller.mp3

4. Müller, Gerd and Newman, Stuart, eds. Origination of Organismal Form (Cambridge, MA: MIT Press, 2003)

5. As they explain in more detail: "Although this theory can account for the phenomena it concentrates on, namely, variation of traits in populations, it leaves aside a number of other aspects of evolution. ... Most importantly, it completely avoids the origination of phenotypic traits and of organismal form. In other words, neo-Darwinism has no theory of the generative. As a consequence, current evolutionary theory can predict what will be maintained, but not what will appear" (Müller and Newman, "Origination of Organismal Form: The Forgotten Cause in Evolutionary Theory," in Origination of Organismal Form, 7). 
today. ${ }^{7}$ It states, in other words, that the mechanism of random mutation and natural selection explains small-scale variations, but does not explain major innovations in the history of life.

And yet, one of the core commitments of theistic evolutionists is the causal adequacy of such evolutionary processes, and the claim that, in some way, God is working through these processes to create. Deborah Haarsma, the president of BioLogos, says "the gradual process of evolution was crafted and governed by God to create the diversity of all life on earth." ${ }^{8}$ She goes on: evolutionary creationists (her term for theistic evolutionists) "accept that natural selection and other evolutionary mechanisms, acting over long periods of time, eventually result in major changes in body structure."

Murray and Churchill have affirmed a similar view. They say, "all versions of theistic evolution affirm that the complexity and diversity of life are best explained by appeal to evolutionary processes that have been operative over long periods of time." They do offer a caveat: "One key process in this synthesis is (mutation and selection).... But it need not be the only important ... process." In other words, Murray and Churchill affirm here that the other evolutionary mechanisms (such as those offered by proponents of the extended evolutionary synthesis) can explain whatever mutation and selection cannot. Thus, they seem to indicate that together various evolutionary mechanisms possess sufficient creative power to account for morphological novelty and biological complexity as it arises in the history of life.

But is that really the case? Interestingly, after the 2016 Royal Society conference in London, one of the key observers, a sympathetic science journalist named Suzan Mazur, wrote a reflective retrospective about the conference and criticized it for its "lack of momentousness." I came away with the same view. The presenters did a good job of explaining the problems with neo-Darwinism, but did not propose or formulate alternative non-neo-Darwinian mechanisms that could adequately account for the explanatory deficits of the mainstream theory or compensate for the lack of creative power associated with its main mutation-selection mechanism.

6. The historical origins of this catchphrase are surprisingly complicated. Most who cite the phrase (e.g., evolutionary biologist Andreas Wagner) credit it to Hugo de Vries, but de Vries himself, in the last sentence of his 1904 monograph Species and Varieties, credits Arthur Harris: "Or, to put it in the terms chosen lately by Mr. Arthur Harris in a friendly criticism of my views: 'Natural selection may explain the survival of the fittest, but it cannot explain the arrival of the fittest'” (Species and Varieties: Their Origin by Mutation, 2nd ed., ed. Daniel Trembly MacDougal (Chicago: Open Court, 1906), http://www.gutenberg.org/files/7234/7234-h/ 7234-h.htm ). For a fuller treatment of the historically complex origins of the phrase, see Glenn Branch, “Whence 'Arrival of the Fittest'?," National Center for Science Education, https://ncse.ngo/whence-arrival-fittest/

7. Andreas Wagner, The Arrival of the Fittest (New York: Penguin, 2014).

8. Haarsma, Deborah, “Evolutionary Creation,” in Four Views on Creation, Evolution, and Intelligent Design, ed. James Stump (Grand Rapids, MI: Zondervan, 2017), 125. See my response, Meyer, Stephen C. "Response to Deborah B. Haarsma," in Four Views on Creation, Evolution, and Intelligent Design, 167-73.

9. Mazur, "Pterosaurs Hijack Royal Society Evo Meeting," Huffpost, November 21, 2016 (updated December 6, 2017), https://www.huffpost.com/entry/pterosaurshijack-royals_b_13131246.
So there is an irony here. At just the time when leading evolutionary biologists are explicitly acknowledging a crisis in the explanatory power of evolutionary theory-in particular, with the mechanisms proposed as the creative engines of evolutionary change-Christian science and faith groups are urging Christians to accept evolution as the means by which God created. But are we really under an epistemic obligation to accept the creative power of random mutation and natural selection, or other evolutionary mechanisms?

Let's examine some of the evidence relevant to answering that question.

\section{The Origin of the Genetic Information Necessary to Produce Novel Protein Folds}

In my book Darwin's Doubt, I discuss one of those big events in the history of life that Craig talked about-the Cambrian explosion. In the process, I explicate four main challenges to the creative power of mutation and selection and other evolutionary mechanisms. These are scientific challenges. I have time to explain only one in detail and to briefly touch on a second.

I want to do so because I think we are far too ready to accept the putative authority of certain mainstream scientists or an alleged “consensus" view. Many people simply assume that nonscientists cannot understand the arguments that are advanced in support of those views and so they readily defer to the perceived consensus. Nevertheless, arguments for the creative power of natural selection and mutation are readily understood. But so are the problems with claims for their creative power.

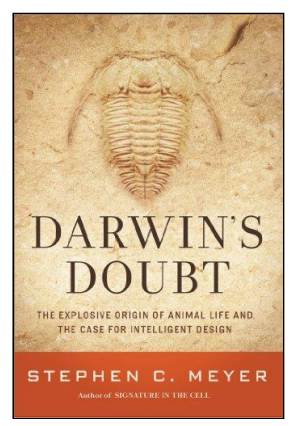

So I would like to explain just one of these problems in a bit of detail. It concerns the origin of genetic information, and what are called protein folds.

If you remember your basic biology, DNA contains information in digital form. That information directs the construction of complex molecules called proteins. Proteins have beautiful three-dimensional shapes that in turn allow them to perform various functions inside cells. Proteins catalyze reactions at rates much faster than would otherwise occur. They build the structural parts of the nanomachines, such as the ribosome and many others, inside cells. They process the information in DNA, among many other functions.

How do we explain the origin of the information that is present in living systems? In Darwin's Doubt, I wrote about the Cambrian explosion, an event in which the major body plans of animals arise abruptly in the fossil record. ${ }^{10}$ In our volume critiquing theistic evolution, paleontologist Günter Bechly and I wrote a chapter about seventeen such major abrupt appearances of new biological form in the history of life as documented in the fossil record. ${ }^{11}$ This pattern of

10. Meyer, Stephen C. Darwin's Doubt: The Explosive Origin of Animal Life and the Case for Intelligent Design (New York: HarperOne, 2013).

11. Bechly, Günter and Meyer, Stephen C. "The Fossil Record and Universal Common Ancestry," in Theistic Evolution, 331-62. 
fossil discontinuity and abrupt appearance is pervasive up and down the stratigraphic column. In any case, when we encounter paleontological events like these and when we think about them from a bioengineering standpoint, or an evolutionary standpoint, these events raise a big question: Where did the information come from to build all these new forms of life?

In the digital world that we ourselves have devised, we know that if we want to give a computer a new function, we have to provide it with new code. The same is true of life. For the evolutionary process to build a new form of life, it needs to produce new organs and tissues, and new cell types. And these new types of cells require new proteins. Constructing new proteins, in turn, requires new information in DNA. So where does that information come from? Could the mutation-selection mechanism produce it?

Some of you remember-just basic biology here-that Watson and Crick discovered the double helix of the DNA molecule in 1953. In 1957, Crick posited the sequence hypothesis: the idea that the chemical subunits known as nucleotide bases along the spine of the DNA molecule function like alphabetic characters in a written language, or digital characters in a section of software. The arrangement of these characters in accord with an independent symbol convention, later discovered and now known as the genetic code, allows the DNA molecule to store and express information. So to build new proteins requires new information encoded in DNA. According to neo-Darwinism, new biological information arises as mutations alter the arrangement of the nucleotide bases (the characters in the genetic text) of a preexisting functional genetic sequence. ${ }^{12}$ But that raises a problem. We know that random changes to a section computer code will tend to degrade the information contained in it. Think about a section of software encoding a program. If you start changing the zeros and ones randomly, you are going to degrade the information and destroy the program, long before you will ever produce a new program or operating system.

There is a reason, in both computer code and in the English language, that functional text is readily degraded by random changes: it turns out that there are far more ways of arranging the relevant characters that will go wrong than go right. Consider, for example, the case of a meaningful twelve letter sequence of English characters. It turns out that there are one hundred trillion ways of arranging twelve English letters that will result in gibberish rather than meaningful words.

Starting in the mid-1960s, some scientists began to wonder if similar considerations applied to DNA and proteins. My colleague Douglas Axe took that question on, and framed it precisely. He put it this way: How common, or rare, are the functional sequences of amino acids that form proteins among all the possible combinations of amino acids of a given length? Or how rare are the functional arrangements of nucleotide base sequences in DNA that code for those corresponding amino acid sequences that make proteins? In English and in computer code we know that there is an enormously and exponentially large number of gibberish sequences in comparison to functional or meaningful sequences. Consequently, a relatively small number of random changes to the characters in a functional or

12. "Random" here should be understood to mean undirected, in the sense that these changes occur without respect to their effect on the fitness of the organism or its offspring. meaningful sequence will almost inevitably destroy the meaning or function of the original functional sequence.

Is this also true in biology? For every folded protein capable of performing a biological function, how many other ways can proteinforming amino acids be arranged?

To answer this question Douglas Axe worked for twelve years at Cambridge University. Using a method of sampling amino acid "sequence space" known as site directed mutagenesis, he came up with an answer: 1 over 10 to the 77 th power. $^{13}$ In other words, he showed that for a protein of modest length there are $10^{77}$ amino acid combinations that will not fold into a protein structure for every one that will. (He also showed that $10^{74}$ amino acid combinations will not fold for every one that will fold in any way at all). In Darwin's Doubt and the volume here under discussion, ${ }^{14}$ I show that even four billion years of replication events, since the origin of life until now, do not provide enough opportunities to effectively search a space of possibilities that large. Thus, the idea that mutation and selection can generate even one new protein fold in the history of life on Earth is implausible in the extreme. That means that random mutation and natural selection does not provide an adequate explanation for the origin of the genetic information necessary to build even a single protein fold, let alone the many proteins required to build new animal tissues, organs or body plans.

\section{Multiple Mutations Destroy the Thermodynamic Stability of Protein Folds}

Let me amplify Axe's conclusion by describing more recent work that we didn't get to discuss in our book critiquing theistic evolution. Dan Tawfik, a protein scientist at the Weizmann Institute in Israel, has shown that there is an underlying thermodynamic reason for the prohibitively small ratio that Axe determined. Tawfik's work also suggests that Axe's results can be generalized. ${ }^{15}$

Remember my analogy to computer code. If we start randomly changing so ware code, the computer program that depends on that code will lose function long before the random changes in the code produce a new functional program or operating system. It turns out that same thing occurs in the case of DNA and proteins.

13. Axe, Douglas "Estimating the Prevalence of Protein Sequences Adopting Functional Enzyme Folds," Journal of Molecular Biology 341 (2004):1295-1315.

14. Meyer, Stephen C. "Neo-Darwinism and the Origin of Biological Form and Information," in Theistic Evolution, 97-129; and Meyer, Darwin's Doubt, 155-208.

15. Tokuriki, Nobuhiko and Tawfik, Dan S. "Stability Effects of Mutations and Protein Evolvability,” Current Opinion in Structural Biology 19 (2009): 596-604, https://doi.org/10.1016/j.sbi.2009.08.003. 
Tawfik's experiments showed that as mutations accumulate, they quickly degrade the structural and thermodynamic stability of protein folds. Yet all protein function depends upon the stability of such folds or what is called tertiary structure. So just as a series of random changes to computer code will destroy the function of the so ware before a new program could arise, a small handful (typically between three and fifteen) random changes to the amino acid sequence in a protein will

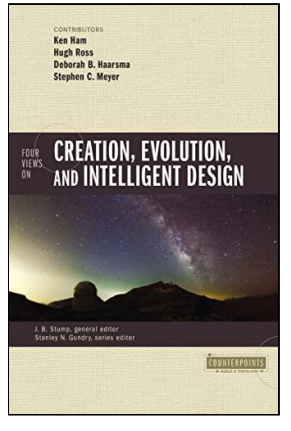
destroy the stability of the protein fold well before enough mutations could accumulate to generate a novel fold. In fact, function-ready protein folds will degrade more quickly than English sentences. Moreover, Tawfik showed that this same thing occurs in large classes of what are called globular proteins, not just the $\beta$-lactamase enzyme that Doug Axe studied, suggesting that Axe's results can be generalized. Finally, there are quantitative implications of Tawfik's work, which reinforce Axe's estimate of rarity as well.

It's important to emphasize that Tawfik is no friend of intelligent design. He is very much a mainstream scientific materialist. Yet he characterizes the origin of new folds as "something close to a miracle." ${ }^{16} \mathrm{He}$ also says elsewhere that we have no evolutionary account for how novel protein folds came to be. ${ }^{17}$

This is highly significant because the protein fold provides the fundamental unit of innovation in biology. The origin of new cell types depends upon the origin of new proteins and protein folds. But since new tissues and organs require new cell types, they too can't arise without new proteins and protein folds to service those cell types and larger structures. We do, of course, have many examples of a small number of mutational changes slightly altering or optimizing the function of preexisting folds. But we have no examples of novel protein folds arising through a series of random mutations. ${ }^{18}$

But it is not only neo-Darwinism that has failed to explain the origin of the information necessary to generate novel folds. The post-neoDarwinian theories and mechanisms of the extended evolutionary synthesis have also failed to do so. Indeed, in Darwin's Doubt and in the volume under discussion here ${ }^{19}$ (with my colleagues Paul Nelson and Ann Gauger), I also evaluate the efficacy of the newer evolutionary mechanisms that biologists have proposed as part of the extended evolutionary synthesis. I have found that these newly proposed evolutionary mechanisms either do not address the

16. Mukhopadhyay, Rajendrani “'Close to a Miracle': Researchers Are Debating Whether Function or Structure First Appeared in Primitive Peptides," ASBMB Today, September 23, 2013, https://www.asbmb.org/asbmb-today/science/ 092313/close-to-a-miracle.

17. Tawfik in a 2016 lecture in Crete: "How did the first enzymes evolve? Because this is a question for which we have basically no answers at the moment." A video of the lecture, "How Do Proteins Evolve?," is available on YouTube: "InnovCrete Seminar: Dan S. Tawfik @ 22/04/2016, 12:00,” https://youtu.be/8ig8vgShZAo.

18. Axe, Douglas D. “The Case against a Darwinian Origin of Protein Folds," BIOComplexity 2010 (2010): 1-12, http://bio-complexity.org/ojs/index.php/main/ article/view/BIO-C.2010.1. Also see my discussion of evolutionary biologists who have proposed that the enzyme nylonase as a counterexample, in Meyer, Stephen C. "Response to Deborah B. Haarsma," Four Views on Creation, Evolution, and Intelligent Design, 167-73.

19. Stephen C. Meyer, Ann K. Gauger, and Paul Nelson, "Theistic Evolution and the Extended Evolutionary Synthesis: Does It Work?," in Theistic Evolution, 249-79. problem of the origin of biological information and protein folds or they do so but only by subtly presupposing other prior unexplained sources of information-that is, they "explain" the origin of biological information only by begging the question as to its earlier or ultimate origin.

\section{The Origin of Developmental Gene Regulatory Networks}

Let me quickly introduce one other related problem: the origin, not just of genes and proteins themselves, but of the complex integrated networks of genes and gene products that form what are called developmental gene regulatory networks (abbreviated dGRNs). To build a new animal body plan, genes and their products must interact in very specific ways, so that genes produce the right proteins and regulatory

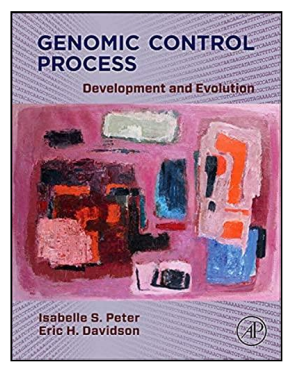
RNAs capable of turning on and off different parts of the genome at just the right times and places during animal development. These networks of genes and gene products are beautifully choreographed to regulate the timing of gene expression as animals develop.

When scientists such as the late Eric Davidson, at Caltech, mapped the functional relationships between the genes, their gene products, and the parts of the genome that they regulate, they invariably produced diagrams that look like integrated circuits. ${ }^{20}$ The dGRNs exhibited that type of integrated complexity.

It is a rule of mechanical and electrical engineering that the more tightly integrated a system is, the more difficult it will be to perturb the system without disrupting the whole. These dGRNs are subject to that same principle of constraint. In fact, Davidson found that any mutation in the core regulatory elements of dGRNs completely shut down animal development. ${ }^{21}$

But that poses formidable problems for evolutionary theory. Building a new animal body plan requires building a novel dGRN. But that means that a preexisting developmental gene regulatory network would need to be transformed into another developmental gene

20. See Peter, Isabelle and Davidson, Eric Genomic Control Process: Development and Evolution (San Diego, CA: Academic, 2015)

21. Davidson writes:

On purely internal considerations, some aspects of dGRN structure appear much more impervious to change than others. For example, a frequently encountered type of subcircuit in upstream regions of dGRNs consists of two or three genes locked together by feedback inputs. ... These feedback structures act to stabilize regulatory states, and there is a high penalty to change, in that interference with the dynamic expression of any one of the genes causes the collapse of expression of all, and the total loss from the system of their contributions to the regulatory state ... [T] hese subcircuits operate at upper levels of dGRN hierarchy so as to affect characters of the body plan that are definitive for upper level taxa, i.e., they control the early stages of just the types of developmental process of which the invariance per taxon constitutes our problem. Since they preclude developmental alternatives, they may act to 'booleanize' the evolutionary selective process: either body part specification works the way it is supposed to or the animal fails to generate the body part and does not exist. (Davidson, Eric "Evolutionary Bioscience as Regulatory Systems Biology," Developmental Biology 357 (2011): 37, 39 (emphasis added)) 
regulatory network. In other words, if you want to go from an existing animal body plan to a novel animal body plan, the evolutionary process would need to generate a novel and functional dGRN. But that would require altering an already-existing dGRN at its deepest nodes. And that is the one thing that Davidson showed empirically does not happen. He showed that developmental gene regulatory networks are resistant to such mutational perturbation. But how then could a new animal body plan-and the new dGRN necessary to produce it-ever evolve from a preexisting body plan and dGRN? Neither neo-Darwinists nor proponents of the extended evolutionary synthesis (or evolutionary creationists) have answered this question.

\section{Excessive Deference}

The problems of (1) the origin of genetic information and new protein folds and (2) the origin of novel gene regulatory networks are just two of several reasons for doubting the creative power of neo-Darwinian and other evolutionary mechanisms.

In making these arguments, those of us in the intelligent design research community have engaged leading evolutionary biologists on the other side. For instance, Darwin's Doubt was reviewed in the journal Science in September 2013 by the terrific evolutionary biologist and Cambrian paleontologist Charles Marshall of University of California-Berkeley. ${ }^{22}$ We later had a great debate on British radio. This was what he wrote in his critical review of my book:

\begin{abstract}
Meyer's case ... depends upon the claim that the origin of new animal body plans requires vast amounts of novel genetic information. In fact, our present understanding of morphogenesis (body plan building) indicates that new phyla were not made by new genes but largely emerged through the rewiring of gene regulatory networks of already existing suites of genes. ${ }^{23}$
\end{abstract}

I appreciated this review because Marshall critiqued what I actually wrote. Even so, his critique was also problematic for several reasons. 22. Marshall, Charles R. “When Prior Belief Trumps Scholarship: Review of Darwin's
Doubt," Science 341 (2013): 1344

23. Ibid

\section{References}

Murray, Michael J. and Churchill, John Ross. “Mere Theistic Evolution” in The 71st Annual Meeting of the Evangelical Theological Society, 2019. https://doi.org/10.54739/6qip

Craig, William Lane. “Response to 'Mere Theistic Evolution'” in The 71st Annual Meeting of the Evangelical Theological Society, 2019. https://doi.org/10.54739/6yr3

Moreland, J. P., Meyer, Stephen C., Shaw, Christopher, Gauger, Ann K., and Grudem, Wayne, eds. Theistic Evolution: A Scientific, Philosophical, and Theological Critique. (Wheaton, IL: Crossway, 2017)

"New Trends in Evolutionary Biology: Biological, Philosophical and Social Science Perspectives.” The Royal Society, https://royalsociety.org/ science-events-and-lectures/2016/11/evolutionary-biology, accessed January 23, 2022

Muller, Gerd. "The extended evolutionary synthesis" http://downloads.royalsociety.org/events/2016/11/evolutionarybiology/muller.mp3, accessed January 23, 2022
First, it presupposed that evolutionary processes can alter developmental gene regulatory networks, which has been shown to be false experimentally by Eric Davidson. In fact, Marshall probably knew that. His University of California-Los Angeles doctoral student Kevin Peterson worked closely with Davidson. ${ }^{24}$ So his claim that "morphogenesis ... largely emerged through the rewiring of gene regulatory networks" is a purely hypothetical and contrafactual postulate.

But, secondly, Marshall presupposed three discrete sources of preexisting unexplained genetic information in his description of the standard account of the origin of animal body plans: (1) The systemslevel information present in the developmental gene regulatory networks, composed of multiple sets of genes operating in close coordination; (2) the lower-level structural genes upon which they act, for building the body parts; and (3) the information needed to "rewire" the gene regulatory networks, which would have require multiple coordinated changes to sections of the genetic text. So to answer the argument that the mutation-selection mechanism (and other similar evolutionary mechanisms) do not explain the origin of genetic information (but instead would have required intelligent design), Marshall responded by simply presupposing several prior unexplained sources of information. One does not need a PhD in biology to understand why this critique is inadequate. Clearly, it begs the question.

In summary, Christian scholars have been entirely too sanguine about, and deferential to, the putative authority of evolutionary biologists and their claims about the sufficiency of evolutionary mechanisms as explanations for the origin of biological complexity and morphological innovation. The focus of attempts by our esteemed colleagues to reconcile evolutionary theory and theism in their "mere theistic evolution" proposal reflects, in my judgment, something of that misplaced deference. That's why I've chosen here to defend our scientific critique of the alleged sufficiency of evolutionary mechanisms as advanced in our book. Based on what I've said, you'll not be surprised to find out that I think our critique stands.

24. Davidson, Eric H., Peterson, Kevin J., and Cameron, Andrew "Origin of Bilaterian Body Plans: Evolution of Developmental Regulatory Mechanisms," Science 270 (1995): 1319-25.

Müller, Gerd and Newman, Stuart eds. Origination of Organismal Form. (Cambridge, MA: MIT Press, 2003)

MacDougal, Daniel Trembly, ed. Species and Varieties: Their Origin by Mutation, 2nd ed. (Chicago: Open Court, 1906)

Branch, Glenn. “Whence 'Arrival of the Fittest'?” National Center for Science Education, https://ncse.ngo/whence-arrival-fittest/, accessed January 23, 2022

Wagner, Andreas. The Arrival of the Fittest. (New York: Penguin, 2014)

Stump, James, ed. Four Views on Creation, Evolution, and Intelligent Design. (Grand Rapids, MI: Zondervan, 2017)

Mazur, Suzan. "Pterosaurs Hijack Royal Society Evo Meeting," Huffpost, https://www.huffpost.com/entry/pterosaurs-hijackroyals b 13131246, published November 21, 2016 (updated December 6, 2017), accessed January 23, 2022 
Meyer, Stephen C. Darwin's Doubt: The Explosive Origin of Animal Life and the Case for Intelligent Design. (New York: HarperOne, 2013).

Axe, Douglas. "Estimating the Prevalence of Protein Sequences Adopting Functional Enzyme Folds." Journal of Molecular Biology 341 (2004):1295-1315

Tokuriki, Nobuhiko and Tawfik, Dan S. "Stability Effects of Mutations and Protein Evolvability." Current Opinion in Structural Biology 19 (2009): 596-604, https://doi.org/10.1016/i.sbi.2009.08.003

Mukhopadhyay, Rajendrani. “'Close to a Miracle': Researchers Are Debating Whether Function or Structure First Appeared in Primitive Peptides," ASBMB Today, https://www.asbmb.org/asbmb-today/science/092313/ close-to-a-miracle, published September 23, 2013, accessed January 23, 2022

Tawfik, Dan S. “How Do Proteins Evolve?” https://youtu.be/8ig8vgShZAo, published April 22, 2016, accessed January 23, 2022
Axe, Douglas D. "The Case against a Darwinian Origin of Protein Folds." BIOComplexity 2010 (2010): 1-12, http://bio-complexity.org/ojs/ index.php/main/article/view/BIO-C.2010.1

Peter, Isabelle and Davidson, Eric. Genomic Control Process: Development and Evolution. (San Diego, CA: Academic, 2015)

Davidson, Eric. "Evolutionary Bioscience as Regulatory Systems Biology." Developmental Biology 357 (2011): 37, 39

Marshall, Charles R. "When Prior Belief Trumps Scholarship: Review of Darwin's Doubt." Science 341 (2013): 1344

Davidson, Eric H., Peterson, Kevin J., and Cameron, Andrew. "Origin of Bilaterian Body Plans: Evolution of Developmental Regulatory Mechanisms." Science 270 (1995): 1319-25. 